\title{
Assessing Swaziland's Fiscal Sustainability and Policy Options
}

\begin{abstract}
Albert Mafusire
Transition Support Department, African Development Bank, Abidjan, Côte d'Ivoire

Correspondence should be addressed to Albert Mafusire; a.mafusire@afdb.org

Received 22 July 2015; Accepted 18 October 2015

Academic Editor: David E. Giles

Copyright (C 2015 Albert Mafusire. This is an open access article distributed under the Creative Commons Attribution License, which permits unrestricted use, distribution, and reproduction in any medium, provided the original work is properly cited.

In 2011, Swaziland's fiscal policy was extensively scrutinized following its worst fiscal crisis in decades. The impacts of fiscal adjustment on Swaziland's growth, inflation, and sectoral allocations of resources were some of the issues analyzed. The fall in the Southern African Customs Union revenue receipts to levels below the trend line, for two consecutive years, and the fiscal challenges that followed were the main motivation behind this interest. This paper attempts to establish whether fiscal sustainability was threatened, and if so what were the policy options? Based on the results from econometric estimations, using a sample for the 1986 to 2012 period, I show that the country's fiscal sustainability was not threatened. However, calculations of the tax gap and the primary gap covering the period 2000 to 2016 reveal that fiscal sustainability was threatened. Subject to the major drivers of government expenditure and revenue handles, it is concluded that, in the short run, the two needed to be realigned while also allocating more resources to support growth.
\end{abstract}

\section{Introduction}

The decline in Southern African Customs Union (SACU) receipts from E7.4 billion in 2014/15 to E6.9 billion for the 2015/16 fiscal year brings back memories of the 2010 to 2013 period. Indeed, the question that would be uppermost every analyst's mind is whether the authorities are prepared to overcome similar challenges this time around if this trend persists for the next two years.

The frequency of fiscal deficits in Swaziland increased since 2000. In 2011, the risks associated with the country's dependency on volatile SACU revenue inflows were exposed, as Swaziland faced its worst fiscal crisis. For over twenty years, the country has maintained a low debt-to-GDP ratio of about 20 percent and has had a clean record with international creditors. The sharp decline in SACU revenue inflows and limited expenditure adjustments, in the aftermath of the global financial crisis, resulted in extreme fiscal stress. Swaziland's failure to secure international funding to close the financing gap worsened the situation. Domestic payments arrears accumulated to more than 5 percent of GDP in 2011 as government failed to meet its obligations in a timely fashion. The fiscal deficit also rose to almost 13 percent of GDP in 2011/12.
Concerns on Swaziland's ability to maintain fiscal sustainability in the short to medium term mounted, specifically due to the expected decline in future SACU revenue receipts. A number of factors accounted for such sentiments on transfers from the Common Revenue Pool (CRP) - deepening regional integration due to the coming into force of the Southern Africa Development Community (SADC) freetrade area (FTA), the discussions on the East and Southern Africa Grand FTA, and global economic developmentswere all likely to result in lower revenue. In addition, although negotiations on a proposed revised revenue sharing formula stalled in 2011, any future efforts in this direction are expected to increase South Africa's share in the CRP. ${ }^{1}$ Botswana, Lesotho, Namibia, and Swaziland (BLNS) countries, therefore, needed to respond to the emerging realities to preserve fiscal and debt sustainability [1].

The fiscal crisis disrupted government programs for two consecutive years. It decimated private sector confidence and negatively impacted investment decisions. The government grappled with reduced financing possibilities, yet its financing requirements had increased. The higher interest costs arising from high borrowing requirements spilled over into the private sector. As the government resorted to domestic borrowing, lending rates increased, thereby crowding out 
the private sector. The increase in the borrowing costs, coupled with nonpayments to suppliers, further curtailed private sector activities. Given that the public sector contributes about 40 percent of GDP economic growth slowed even further. Consequently, the tax base shrunk and this risked widening of the fiscal deficit.

Previous studies on Swaziland's fiscal balances focused on identifying fiscal adjustment options that had minimal impact on other macroeconomic variables. Basdevant et al. $[2,3]$ investigated the relative impacts of different fiscal adjustments on growth while Mongardini et al. [1] investigated the implications of such adjustments on growth, inflation, and sectoral resource allocations. In this study, the question is whether Swaziland's recent fiscal developments posed a threat to its fiscal sustainability. Theoretically, fiscal sustainability analysis is concerned with whether current government fiscal policy could be continued into the future without threatening government solvency [4]. In this context, I posit that Swaziland's fiscal sustainability was threatened and needed significant adjustment. In addition, this paper argues that focusing on reducing government expenditure alone may not have been the optimal policy stance.

Drawing from the results of the analysis in this paper I conclude that Swaziland needed to reduce its public deficit to about 1 percent of GDP to ensure fiscal sustainability. As with Mongardini et al., [1] I also recommend reallocation of government expenditure from current to capital expenditure so as to support growth.

The rest of the document is organized as follows. Section 2 provides a brief analysis of Swaziland's recent growth and dependence on SACU revenues. Section 3 covers fiscal performance in detail and Section 4 presents the theoretical analysis of fiscal sustainability. Section 5 discusses the policy options and provides some recommendations before the conclusions in Section 6.

\section{Macroeconomic Developments}

2.1. Economic Growth. Unlike its regional peers in Southern Africa, Swaziland experienced sluggish growth in the decade since the turn of the century, averaging only 2.2 percent per year (Figure 1). Its growth was driven largely by public consumption, while private consumption growth was curtailed by slow income growth. Although Swaziland's growth slowed only marginally when the global financial and economic crisis hit in 2009, the rebound in output growth to 2.0 percent in 2010 was subdued. In 2011, growth slowed to just over one percent and further declined to 0.7 percent in 2012 [5].

Swaziland's persistently low growth reflected the structural weaknesses and limited reforms, all of which contributed to the high cost of doing business. Other factors, including unfavorable weather conditions, low levels of foreign direct investment, and low productivity, negatively impacted economic growth.

2.2. Fiscal and Debt Performance. Inflows from the Common Revenue Pool (CRP) were uncertain and volatile (Figure 2 and Table 1) despite constituting a large proportion of total

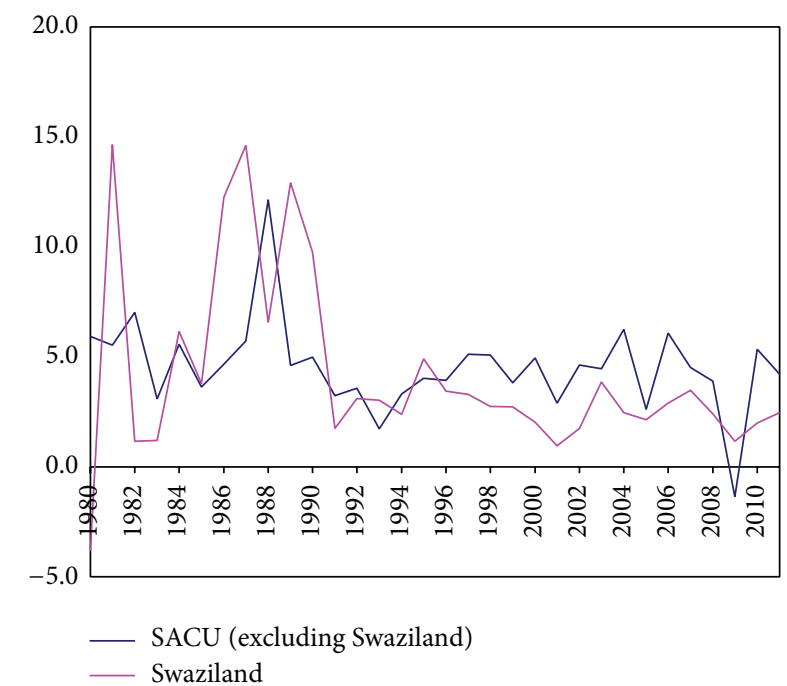

Figure 1: Trends in SACU growth (\%). Source: GoS, SACU Secretariat.

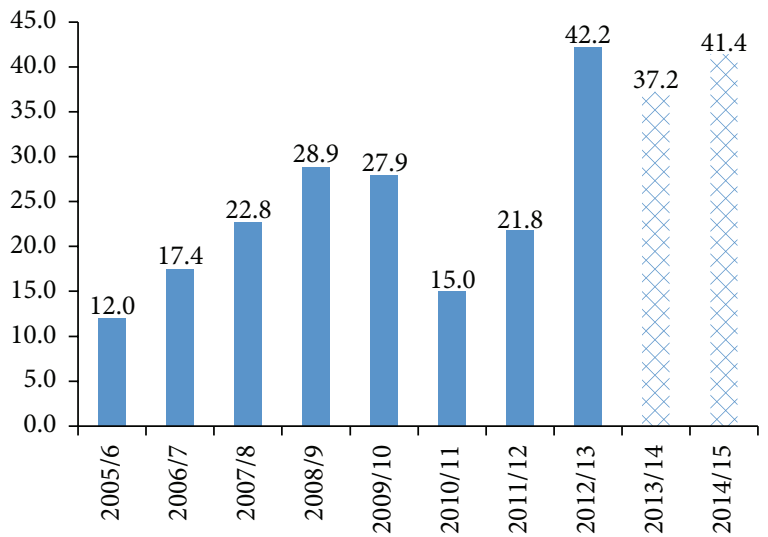

FIGURE 2: CRP transfers to BLNS countries (bn). Source: GoS, SACU Secretariat.

government revenue in BLNS countries before the crisis (about 50 percent in Lesotho, nearly 40 percent in Namibia, and more than two-thirds in Swaziland). The volatility of these inflows from the CRP, therefore, had a destabilizing effect on the smaller SACU economies.

In Swaziland, dependency on a highly volatile revenue source was reflected in trends in fiscal deficits and capital expenditure. Capital expenditures were consistently below 10 percent of GDP thereby negatively impacting its competitiveness and growth potential. Both debt and effective interest rate payments on debt rose on the back of high fiscal deficits. Important adjustments needed to rectify the worsening fiscal position did not take place thus magnifying the risk of fiscal and debt unsustainability.

The frequency of fiscal deficits increased in the last decade, with fiscal surpluses occurring in only three out of the ten years. In 2010, the deficits breached the 10 percent level for the first time in over 20 years. Such large swings in fiscal balances are considered harmful to growth and welfare [6]. At 0.57 , volatility as measured by the standard deviation 
TABLE 1: Revenues as percent of GDP.

\begin{tabular}{lcccccccccc}
\hline & $2001 / 02$ & $2002 / 03$ & $2003 / 04$ & $2004 / 05$ & $2005 / 06$ & $2006 / 07$ & $2007 / 08$ & $2008 / 09$ & $2009 / 10$ & $2010 / 11$ \\
\hline Tax category & & & & & & & & & \\
$\quad$ Income taxes & 6.2 & 6.4 & 7.9 & 7.4 & 7.7 & 7.7 & 7.7 & 7.7 & 8.6 & 9.5 \\
Property taxes & 0.0 & 0.0 & 0.1 & 0.1 & 0.1 & 0.1 & 0.1 & 0.1 & 0.1 & 0.1 \\
Goods and services tax & 17.6 & 17.6 & 18.2 & 22.1 & 24.0 & 30.6 & 27.5 & 28.8 & 23.9 & 14.8 \\
SACU revenue & 12.9 & 12.5 & 13.4 & 17.7 & 19.1 & 26.7 & 23.3 & 24.1 & 19.4 & 9.7 \\
Nontax revenue & 1.8 & 1.3 & 3.1 & 0.6 & 0.9 & 1.0 & 1.6 & 1.9 & 1.4 & 1.0 \\
Total revenue & 25.6 & 25.4 & 29.2 & 30.2 & 32.7 & 39.4 & 36.9 & 38.5 & 34.0 & 25.4 \\
Less SACU revenue & 12.7 & 12.8 & 15.9 & 12.5 & 13.6 & 12.7 & 13.6 & 14.4 & 14.6 & 15.7 \\
\hline
\end{tabular}

Source: Swaziland Revenue Authority.

had been increasing since 1986 although the series was mean reverting.

High volatility of the primary balance increased uncertainty and raised the premium that the government had to pay when borrowing from the financial market. In addition, the financial markets' appetite for long-term government bonds fizzled out. The Government of Swaziland failed to raise sufficient funds through a 7-year bond issued in December 2010, with the market subscribing to about 20 percent of the bond offer. As long-term borrowing became difficult, larger cuts on capital expenditure relative to that on recurrent expenditures were effected (Figure 4). In addition, the government ran down its deposits with the Central Bank and accumulated domestic payments arrears. Foreign reserves had declined by almost 48 percent to Emalangeni 3.8 billion by end of March 2012, which was equivalent to only 1.9 months of imports compared to 4.7 months of import cover before the global financial crisis. Also debt rose to 17 percent of GDP in 2011/12 (Figure 3 ) from 12.5 percent in $2009 / 10$. Without adjustments to expenditure to match the revenue flows, debt was projected to increase to almost 35 percent by 2015/16 [2]. Access to proposed South African (SA) and African Development Bank (AfDB) debt would have resulted in a debt rising to about 28 percent of GDP.

In Figure 5, it is important to observe that although the debt to GDP ratio was falling until 2009, real GDP growth also fell. The recent increase in the debt to GDP ratio (see Figure 3) when growth remains depressed (see Figure 1) raises alarm bells for fiscal sustainability.

\section{Understanding Fiscal Sustainability}

At an analytical level, solvency is distinguished from fiscal sustainability. Government solvency is satisfied when its current assets and future revenue flows are adequate to cover its current and future debts. This condition requires that government finances satisfy the intertemporal budget constraint, where present and future assets are used to offset present and future liabilities [7]. Solvency can be achieved after large and costly adjustments to fiscal policies. Fiscal sustainability, on the other hand, requires that government current policies could be maintained without risking its solvency [8]. Alternatively, fiscal sustainability refers to policies that would ensure nonincreasing government debt.

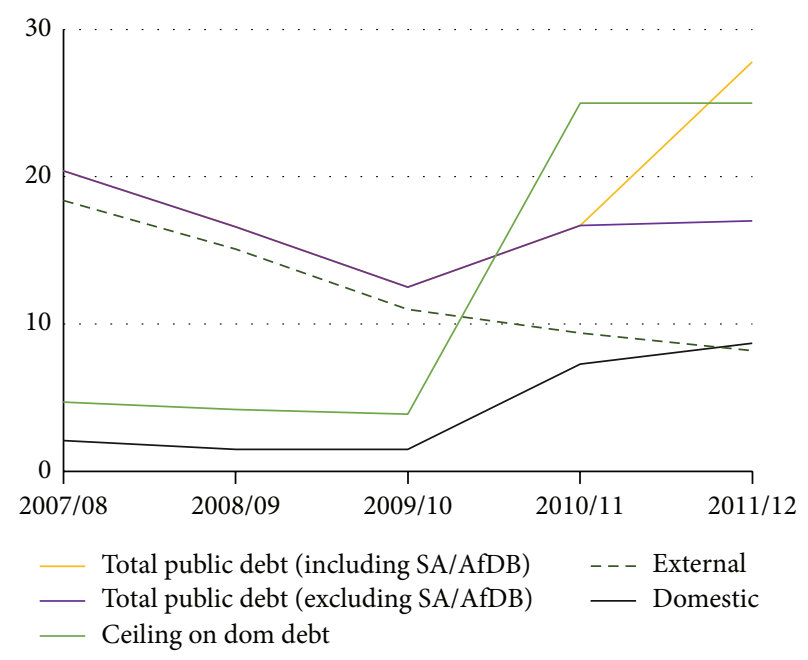

FIGURE 3: Public debt (\% of GDP). Source: Government of Swaziland.

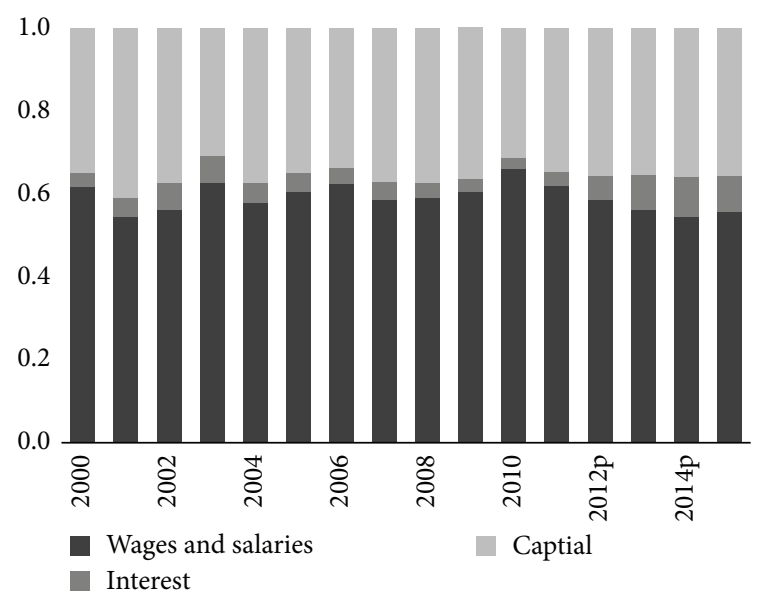

FIGURE 4: Broad government expenditure shares. Source: Government of Swaziland.

Despite the importance of fiscal sustainability to governments, neither the concept is precisely defined nor there is a single indicator for its measurement. As a result, the concept of sustainability is not without controversy [9]. At a theoretical level, nonincreasing debt-to-GDP ratio implies 


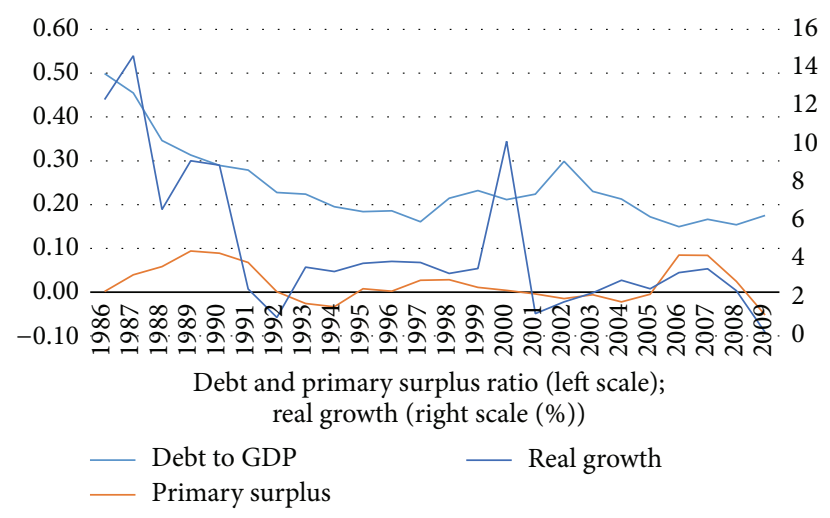

Figure 5: Trends in key variables. Source: Government of Swaziland.

that it has a constant mean. Yet there is no reason why it should not be any other stable level, be it lower or higher.

At a practical level, varying thresholds for government debt and fiscal deficits necessary for fiscal sustainability have been set based on historical experiences. The Maastricht criteria for fiscal convergence in the EU require that countries maintain debt-to-GDP ratios of not more than 60 percent and fiscal deficits are capped at 3 percent. ${ }^{2}$ SADC set similar thresholds to those in the EU under the macroeconomic convergence criteria for the period 2012 to $2018 .^{3}$ In the case of Swaziland, the IMF recommended a debt threshold of 40 percent of GDP [1]. The level of the fiscal deficit consistent with the debt threshold is therefore a derived outcome.

We observe that both solvency and sustainability have long-term connotations. The state is a perpetual entity, which allows government's fiscal policies to increase fiscal deficits such that they can achieve their short-term objectives. However, such increases in deficits would have to be compensated in the future to ensure solvency. The readjustment process would require significant changes to the fiscal policy.

The present value budget constraint (PVBC) approach allows temporary deviation from a zero budget balance. However, large fiscal deficits raise two separate but related concerns: (i) shifting the tax burden of the current generation to future generations and (ii) "crowding out" of private investment and thus diminishing economic growth potential [10].

Failure to realign expenditures to revenues would result in fiscal crises that take one of two forms, that is, a liquidity crisis or solvency crisis [11]. In 2011, the IMF noted that although Swaziland's debt-to-GDP ratio was only around 20 percent, it faced a serious liquidity crisis that could quickly develop into a solvency crisis. The implications are that Swaziland faced a short-term cash flow imbalance that could be corrected through access to external or internal financing without threatening solvency. The Government committed itself to implementing an IMF Staff Monitored Program (SMP) that included short-term measures that would result in an inflow of external resources in the form budget support. These measures included a 10 percent cut in civil service wages to reduce expenditures while enhancing revenue mobilization to correct the fiscal imbalance.

Although progress was made regarding revenue mobilization and implementation of measures to reduce wastage in current expenditures, there was resistance to cutting the civil service wages. The SMP was assessed unsatisfactory, blocking the country's access to E2.4 billion in budget support from the African Development Bank and South Africa. Assuming access to budget support, debt would have increased to more about 28 percent of GDP. Without any changes in policy, there was a risk that debt could rise to more than 40 percent.

\section{Assessing Fiscal Sustainability}

4.1. Methodological Issues. Fiscal outcomes, in part, are a reflection of political considerations regarding revenue and spending decisions. ${ }^{4}$ Therefore, clear understanding of how such decisions impact on fiscal and subsequently debt sustainability is important. The starting point is to identify the key variables that influence the fiscal balance and also how unsustainable fiscal balances would translate into a debt crisis. I consider these two issues separately below.

Among the factors that impact on fiscal sustainability are taxes, government expenditure, commodity prices, exchange rates, interest rates, economic growth, inflation, and changes in the population structure. High commodity prices tend to impact growth positively and government expenditure is adjusted upwards during such periods of economic expansion. However, when commodity prices fall, expenditures tend to adjust only sluggishly while at the same time negatively impacting the tax levels, resulting in increases in the primary deficit. Reinhart and Rogoff [12] found that when world commodity prices are low, the default rate on public debt is high. Also when commodity prices are high, access to debt is easier thereby exposing the countries to higher default risks when the commodity price boom reverses.

Inflation and the exchange rate potentially affect fiscal budget, especially under floating exchange rates. Addressing inflation therefore would also require adjustment to interestbearing public debt [13]. Exchange rate movements however have a less clear impact on fiscal deficits and debt. For countries that have a negligible level of foreign debt and where the tradable sector output increases significantly, tax revenues will increase helping reduce the deficit. However, when the terms of trade effect are strong and impact growth negatively, the opposite result will emerge.

High commercial or political risk is positively correlated with interest rates. Higher interests in turn increase the cost of debt, crowd out the private sector, and therefore reduce investment leading to depressed growth. Also changes in the population dependency ratio may increase the public obligation for social expenditures, potentially raising fiscal deficits especially when political considerations militate against tax increases.

This analysis focuses on six key variables, which are taxes, government expenditure, primary surplus, public debt, interest rates, and growth. All the variables, except interest rates and GDP growth, are expressed as ratios of GDP. 
TABLE 2: Evolution of key macroeconomic variables (GDP ratios) ${ }^{*}$.

\begin{tabular}{|c|c|c|c|c|c|c|}
\hline & Tax & Expenditure & Primary surplus & Debt & Growth & Interest rate \\
\hline 2000 & 0.24 & 0.27 & 0.004 & 0.21 & 0.10 & 0.03 \\
\hline 2001 & 0.24 & 0.29 & -0.004 & 0.22 & 0.02 & 0.04 \\
\hline 2002 & 0.24 & 0.30 & -0.015 & 0.30 & 0.02 & 0.06 \\
\hline 2003 & 0.26 & 0.30 & -0.006 & 0.23 & 0.02 & 0.05 \\
\hline 2004 & 0.30 & 0.34 & -0.022 & 0.21 & 0.03 & 0.05 \\
\hline 2005 & 0.32 & 0.34 & -0.005 & 0.17 & 0.02 & 0.06 \\
\hline 2006 & 0.38 & 0.30 & 0.084 & 0.15 & 0.03 & 0.06 \\
\hline 2007 & 0.35 & 0.32 & 0.084 & 0.17 & 0.04 & 0.06 \\
\hline 2008 & 0.37 & 0.38 & 0.024 & 0.15 & 0.02 & 0.06 \\
\hline 2009 & 0.33 & 0.40 & -0.052 & 0.17 & 0.01 & 0.06 \\
\hline 2010 & 0.22 & 0.37 & -0.116 & 0.13 & 0.02 & 0.07 \\
\hline 2011 & 0.23 & 0.34 & -0.100 & 0.17 & 0.01 & 0.08 \\
\hline 2012 & 0.24 & 0.33 & -0.051 & 0.17 & 0.01 & 0.08 \\
\hline
\end{tabular}

Source: MoF, Government of Swaziland.

${ }^{*}$ Except interest rates and GDP growth.

The evolution of these variables, since 2000, is presented in Table 2. Section 2 provides details on how these variables have evolved over time.

Given the multiplicity of variables that potentially affect fiscal sustainability, the commonly applied analytical framework is the intertemporal budget constraint. For sustainability to be achieved, "the discounted value of current and future income plus initial wealth should at least be equal to the discounted value of all current and future noninterest expenditure" [14]. The static budget constraint is therefore expressed as

$$
b_{t}=b_{t-1}+d_{t}+r d_{t-1}
$$

where $b_{t}$ is the current period government debt stock, $r$ is the interest rate, and $d_{t}$ is the current period primary deficit. The above expression shows that changes in the interest rate affect the cost of previous deficits and therefore the current debt level. Expressing the debt and primary deficit as ratios to GDP and solving backwards to the initial period, the intertemporal budget constraint is obtained; that is,

$$
b_{T}=b_{0}\left(\frac{1+r}{1+y}\right)^{T}+\sum_{t=1}^{T} d_{t}\left(\frac{1+r}{1+y}\right)^{T-t} .
$$

Based on (2), either a decrease in interest rates or growth in GDP would result in the debt ratio falling if no further fiscal deficits are incurred. It is in this context that governments are encouraged to make adjustments to their revenue and expenditure positions to address any fiscal pressures. When discounted and assuming an infinite time horizon, (2) becomes

$$
\lim _{T \rightarrow \infty}\left[b_{T}\left(\frac{1+r}{1+y}\right)^{-T}\right]=b_{0}+\lim _{T \rightarrow \infty}\left[\sum_{t=1}^{T} d_{t}\left(\frac{1+r}{1+y}\right)^{-t}\right]
$$

Assuming an infinite time horizon and imposing a no-Ponzi game restriction, the left hand side of (3) is zero; thus, the sustainability condition is

$$
-b_{0}=\lim _{T \rightarrow \infty}\left[\sum_{t=1}^{T} d_{t}\left(\frac{1+r}{1+y}\right)^{-t}\right] .
$$

Based on (4), although debt can deviate from its current level, its growth must be lower than the difference between the interest rate and real GDP growth; that is, $\Delta b<r-y$. Alternatively, expression (4) says a country could increase its liabilities for as long as its assets are growing at the same rate as interest payments without negatively impacting on its sustainability.

With reference to (4) the intertemporal budget constraint framework allows econometric specifications that could be tested for fiscal sustainability. Cointegration analysis has been empirically applied to test for fiscal sustainability $[11,15,16]$. According to Trehan and Walsh [15], an important condition for fiscal sustainability is that debt and fiscal deficits are cointegrated or alternatively that the primary surplus is stationary. On the other hand, Bohn [16] suggests that if the current change in the debt to GDP ratio is negatively related to the previous period debt to GDP ratio but positively related to government expenditure and output gaps, the fiscal policy is sustainable. This relationship is specified as follows:

$$
b_{t}=\alpha_{0}+\alpha_{1} b_{t-1}+\alpha_{2} g_{\mathrm{gap}_{t}}+\alpha_{3} y_{\mathrm{gap}_{t}}+\varepsilon_{t},
$$

where $g_{\text {gap }}$ is the variation of current government expenditure from its permanent level, $y_{\text {gap }}$ is the variation of current output from its permanent level, and $\varepsilon_{t}$ is an error term. Thus, fiscal sustainability would require that $\alpha_{1}$ is negative while $\alpha_{2}$ and $\alpha_{3}$ are positive. As will be observed below, given (6), this conditions implies that the primary surplus must be a strictly positive function of the debt to GDP ratio for fiscal sustainability. Additionally, Celasun et al. [17] employ an unrestricted vector autoregression (UVAR) model comprising foreign and domestic interest rates, real GDP growth, and 
real exchange rates to obtain a variance-covariance matrix of the debt determinants, which are used in a Monte Carlo simulation. In this analysis, if the variance-covariance matrix is orthogonal, at least one of the explanatory variables should be cointegrated with debt.

While econometric methods have been used in projecting the future sustainability of fiscal policy, there are limitations. First, (5) is backward looking; yet sustainability analysis has greater value when it can provide an indication of the implications of current policies on future fiscal outcomes. Second, forecasts of sustainability based on econometric analysis may have large errors when long future periods are considered due to uncertainty [9]. Indicators of fiscal sustainability therefore have been derived from the intertemporal debt accounting identity. This paper applies a stochastic model based on stationarity conditions and also calculates two indicators of fiscal sustainability based on the pioneering work by Blanchard [18].

4.2. Results and Interpretations. Time series data for the period 1986-2009 on debt $(B)$, primary deficit $(D)$, effective interest rates $(r)$, GDP and its real growth $(y)$, government expenditure (GE), and tax revenue (TAXR) were collected from the IMF and government sources. The effective interest rate is derived as the ratio of interest payment on debt divided by the debt level. These variables were normalized using GDP, except for the effective interest rates and real GDP growth. I also generate permanent government expenditure and output using the Hodrick-Prescott filter, from which I derive the government expenditure and output gap to GDP ratios.

Adapting (5) above, I use Bohn's [16] stochastic specification of the primary surplus; that is,

$$
d_{t}=\alpha b_{t}+\delta Z_{t}+\varepsilon_{t}=\alpha b_{t}+\mu_{t}
$$

where $Z_{t}$ is a vector of determinants of the primary deficit, which includes the output gap, lagged primary deficits, and debt. According to Chalk and Hemming [8], if $d_{t}$ and $b_{t}$ are nonstationary and $\mu_{t}$ is stationary, then cointegration tests have to be carried out. On the other hand, if $d_{t}$ and $b_{t}$ are stationary, omitting $Z_{t}$ would result in biased coefficient estimates. Stationarity tests of the elements of $Z$ are presented in Table 3. Through an estimation of (6), fiscal sustainability is confirmed if $\alpha>0$.

All the relevant variables are observed to be stationary. Four primary deficit models were estimated and the results are presented in Table 4. Although the debt coefficient has the right sign in model 3 , it is not statistically significant. In model 2, debt has the expected sign and is significant but there is serious autocorrelation and low explanatory power. Lastly in model 4, both the lagged debt and primary deficit variables reasonably explain movements in the current primary deficit. These results suggest sustainability of fiscal policy, at a deficit of about 2 percent of GDP. In this context, Swaziland' fiscal position was sustainable over the sample period.

Considering that the magnitude and frequency in fiscal deficits have increased in recent years, especially after 2000, the sustainability of Swaziland's fiscal position becomes questionable. Moreover, the 2 percent threshold for fiscal
TABLE 3: Unit root test results, Phillips-Perron test statistic.

\begin{tabular}{lcc}
\hline Variable & $\begin{array}{c}\text { Adjusted } \\
t \text {-statistic }\end{array}$ & Probability \\
\hline Debt to GDP ratio & -3.9177 & 0.0054 \\
Primary surplus to GDP ratio & -2.9980 & 0.0465 \\
Interest rate & -2.8934 & 0.0615 \\
GDP growth & -2.8189 & 0.0712 \\
Output gap & -5.5909 & 0.0001 \\
\hline MacKinnon (1996) [19] test critical & & \\
values: & & \\
$\quad$ 1\% level & -3.752942 & \\
5\% level & -2.998064 & \\
$10 \%$ level & -2.638752 & \\
\hline
\end{tabular}

sustainability to hold is higher than a deficit of $1.1 \%$ as established in Basdevant et al. [3]. The situation is more poignant when a projection of the primary deficit for the period 2013 to 2016 is taken into account. Using an alternative methodology based on the calculations of fiscal sustainability indicators, I come to a different conclusion to that established above. The analysis below provides the details.

Using the accounting identity as presented in (1), two main indicators of fiscal sustainability have been developed and these are the primary deficit gap and the tax gap [9, $18,20]$. As with debt sustainability, the intertemporal budget constraint constitutes the foundations of these indicators. ${ }^{5}$ Essentially, the derivation of the primary deficit gap starts with establishing the condition for a constant primary deficit, which is given as

$$
d^{*}=-b_{0}(r-y)
$$

The primary gap is therefore expressed as follows:

$$
d^{*}-d_{t}=-b_{0}(r-y)-d_{t}
$$

From (8), if $d_{t}>d^{*}$, then debt would rise continually and thus fiscal policy would be deemed unsustainable. In this context, the primary gap indicates the level of adjustment that is required if sustainability is to be maintained. To obtain these indicators, some assumptions have to be made about interest rates and GDP growth.

Despite the uncertainty associated with future values of most economic variables, it is important that arbitrariness in the assumed variable trends is avoided whenever possible. Alternatively, finite horizon indicators are computed. This requires some modifications to the derivation of the indicators [9]. In some instances, time series analysis has been used to forecast values of the key variables that could be used in the calculations. In this paper, I adopt a finite time horizon in computing the sustainability indicators. When the primary gap indicator is below zero, it is considered to be unsustainable. Figure 6 presents a plot of the primary gap indicator (including the trend line equation) where it is observed that for the recent period (2009-2012) fiscal policy had increasingly become unsustainable and likely to remain so up to 2016 (based on projections) if no adjustments to 
TABLE 4: OLS estimation results (Dependent variable, primary surplus).

\begin{tabular}{|c|c|c|c|c|}
\hline \multicolumn{5}{|c|}{ Coefficients and model test indicators } \\
\hline Independent variable & Model 1 & Model 2 & Model 3 & Model 4 \\
\hline Constant & - & -0.031 & -0.026 & - \\
\hline$b_{t}$ & - & - & 0.159 & - \\
\hline$b_{t-1}$ & -0.168 & $0.135^{*}$ & - & $0.047^{*}$ \\
\hline$b_{t-2}$ & 0.203 & - & - & \\
\hline$y_{\text {gap }_{t}}$ & 0.055 & - & 0.181 & \\
\hline$y_{\text {gap }_{t-1}}$ & - & $-2.78 E-05^{* *}$ & -0.170 & \\
\hline$d_{t-1}$ & $1.011^{* *}$ & $0.728^{* *}$ & $1.113^{* *}$ & $1.087^{* *}$ \\
\hline$d_{t-2}$ & -0.660 & & $-0.699^{* *}$ & $-0.719^{* *}$ \\
\hline$R$-squared & 0.695 & 0.529 & 0.671 & 0.656 \\
\hline Adjusted $R$-squared & 0.623 & 0.455 & 0.568 & 0.620 \\
\hline S.E. & 0.026 & 0.031 & 0.028 & 0.026 \\
\hline Durbin-Watson Statistic & 2.357 & 1.220 & 2.209 & 2.236 \\
\hline Mean of dependent variable & 0.019 & 0.200 & 0.019 & 0.019 \\
\hline
\end{tabular}

Note: ${ }^{*} 10 \%$ significance level, ${ }^{* *} 1 \%$ significance level.

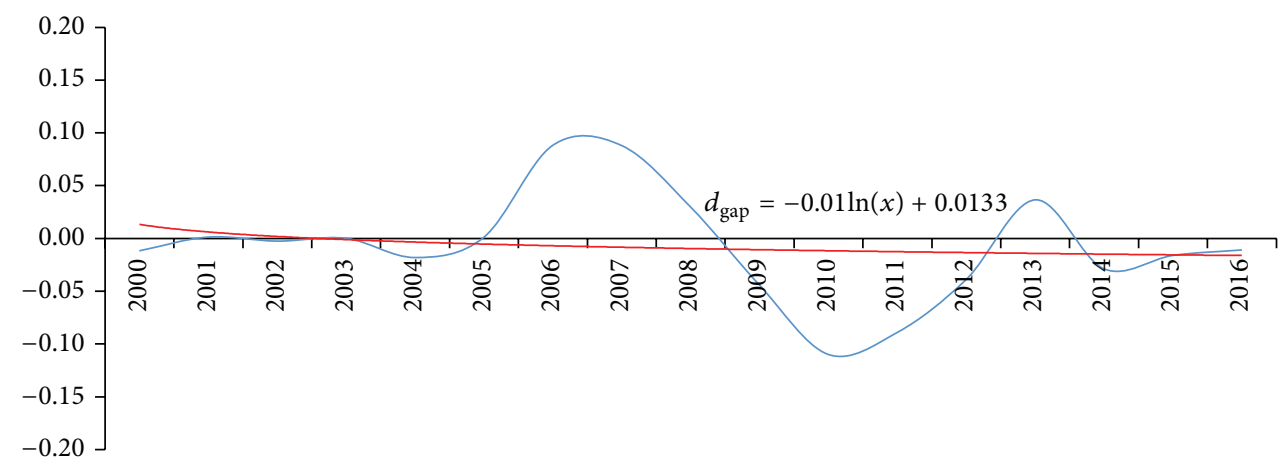

FIgURE 6: Primary gap indicator, based on author's calculations.

expenditure were made. Adding a trend line, the overall primary gap indicator suggests overall fiscal unsustainability from about 2003.

Making substitutions and expressing the primary deficit as the difference between expenditure and revenues, another indicator, the tax gap $\left(t_{\text {gap }}\right)$ is derived as

$$
t_{\text {gap }}=t^{*}-t
$$

where $t^{*}$ is the sustainable level of revenue and $t$ is the current revenue. Following the determination of the permanent level of output above, the Hodrick-Prescott filter is used to obtain the permanent tax level.

Using the tax gap indicator, it is also observed that the fiscal conditions prevailing in Swaziland were not sustainable (Figure 7). For the tax gap indicator, values above zero suggest fiscal unsustainability. The trend line is above zero for all the period beginning in 2000. In both of Figures 6 and 7, it is observed that Swaziland has moved further away from fiscal sustainability in more recent years than before the fiscal crisis.
Given the fiscal policies in recent years, I assess how much effort would be required to return to fiscal sustainability. Figure 8 plots three scenarios: (i) historical, (ii) Fiscal Adjustment Roadmap (FAR), and (iii) sustainable deficit scenarios. Considering fiscal sustainability as a constant debtto-GPD ratio or zero growth in the debt-to-GPD implies that a country would maintain fiscal sustainability if debt obligations and its capacity to pay back debt increase at the same rate. In this context, the difference between the longterm primary balance and the primary gap would measure the amount of efforts required to ensure the primary gap is equal to zero in the long term. This is what I refer to as the sustainable primary deficit. Plotting the sustainable primary gap against the historical and also the updated FAR (UFAR) primary balance scenarios provides a visual image of the effort required to achieve sustainability (Figure 8). I observe that both the UFAR and historical scenarios are way below the sustainable primary deficit. On average, the sustainable deficit should be at most 2 percent of GDP. When compared to the average deficit to GDP ratio of almost 4 percent over the 2007/8-2015/16, the historical deficit is two times higher than the sustainable level. While the updated FAR (UFAR) 


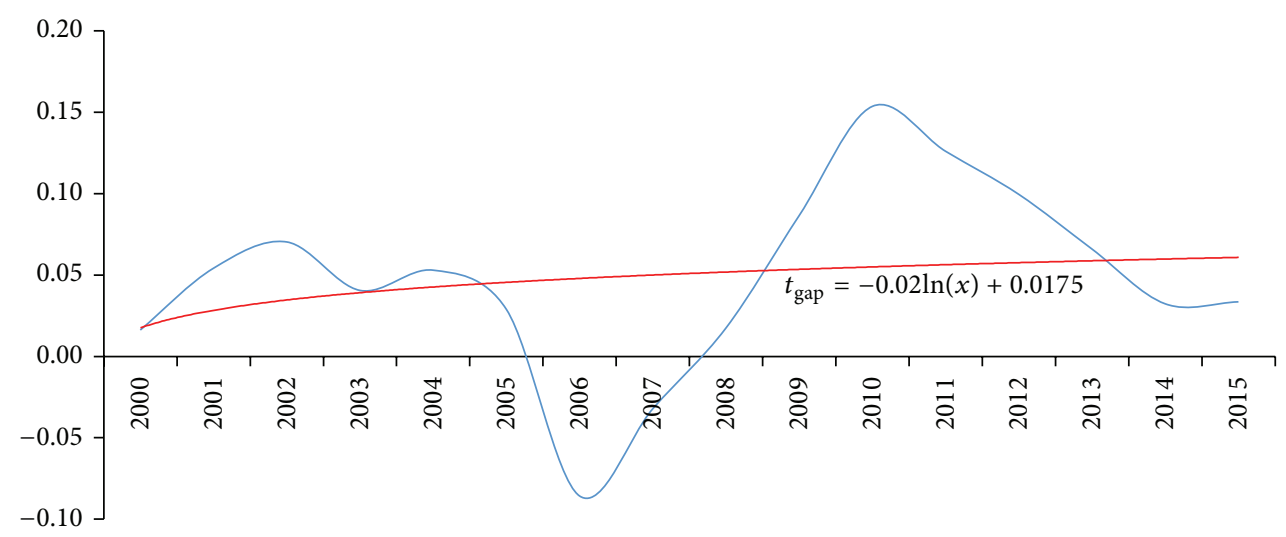

FIGURE 7: Tax gap indicator, based on author's calculations.

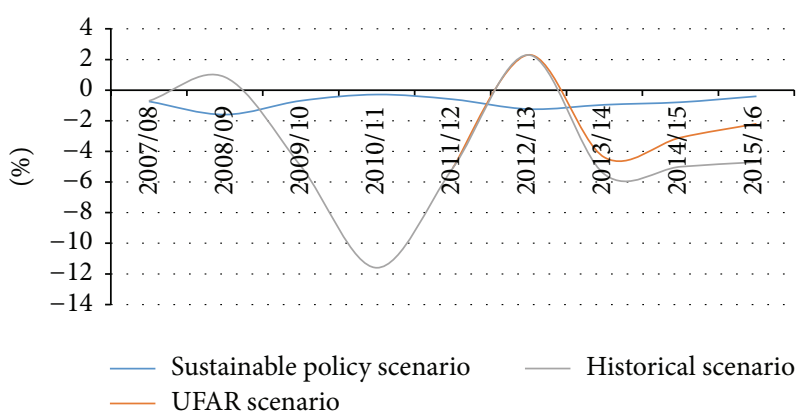

FIGURE 8: Effort to fiscal sustainability. Source: based on author's calculations.

scenario yields a smaller average fiscal deficit of $2.5 \%$ of GDP compared to the historical scenario, it is still unsustainable by about $0.5 \%$.

\section{Policy Options}

On the basis of the fiscal sustainability indicators, one would infer that policies that reduce interest rates and/or raise economic growth would increase the country's fiscal deficit tolerance levels. Higher growth would improve the country's capacity to service its debt. However, the structural constraints facing Swaziland make achieving higher growth levels a real challenge.

In the short term, revenue and expenditure adjustments are needed to correct fiscal imbalances. In 2010, the Swaziland Revenue Authority (SRA) was established with the aim to enhance efficiency in revenue mobilization. New taxes such as Value Added Tax (VAT) were introduced, which improved revenue collection by more than one and a half percentage point of GDP. New tax policy changes were unlikely, especially during an election year. Expenditure adjustments therefore were the most feasible option for the very short term but this tended to hit hard on capital expenditure therefore negatively impacting growth. Cuts in wages proved difficult and this remained a sticking point that resulted in the unsuccessful implementation of the IMF Staff Monitored Program in 2011.
TABLE 5: Revenue elasticities.

\begin{tabular}{lc}
\hline Revenue type & Elasticity \\
\hline Income tax & 1.3 \\
Property tax & 1.4 \\
Nontax revenue & 0.6 \\
Goods and services tax & 1.3 \\
Total revenue & 1.3 \\
\hline
\end{tabular}

Source: author's calculations.

In spite of the difficulties facing the government, returning to fiscal sustainability in the short to medium term inherently called for some hard choices. First, expenditure reductions needed to be accompanied by reallocation of public expenditures from consumption to capital investments. Capital expenditures accounted for less than 10 percent of GDP and reallocation in expenditure away from recurrent to the capital budget should be a priority. Second, structural policy measures to improve the business environment in order to attract both domestic and foreign investments would improve the medium term fiscal outcomes. An improved business environment supports private sector development, growth, and jobs creation. In addition, growth would enhance tax levels, especially with the establishment of the SRA. To evaluate this relationship, I run least squares estimations of the log of each tax handle as the dependent variable against the log of GDP. The coefficients from this estimation are the elasticities which are presented in Table 5. Swaziland's tax elasticities show that, for every one percentage increase in growth, total tax revenue would increase by 1.3 percent.

Finally, improvements in budget control were important to reduce wastage of public funds in public service delivery. Such improvements, however, did not provide a lasting solution to the expenditure allocation problem. Therefore, comprehensive public financial management reforms are critical to ensuring fiscal sustainability.

\section{Conclusions}

Fiscal developments in the aftermath of the global financial crisis presented a risk to Swaziland's fiscal sustainability, 
despite the low debt-to-GDP ratio that the country enjoyed. The frequency of fiscal deficits and their magnitude increased. Econometric analysis carried out in this paper confirms that Swaziland's fiscal sustainability was not threatened. However, the calculated fiscal indicators using macroeconomic data under the assumption of limited fiscal adjustments suggest that Swaziland needed greater effort to return to sustainability than was proposed under the updated FAR. Given the limited potential to enhance revenues, especially following the recent tax policy changes and efficiencies from the establishment of the Swaziland Revenue Authority, more focus needed to be placed on expenditure adjustments for the very short term. In the medium term, fiscal sustainability was to be achieved through growth enhancing measures, mainly those that address the structural weaknesses of the economy. Also the government needed to rebuild confidence in the economy with a view to reducing the cost of debt and ensuring more private sector investments.

\section{Disclaimer}

All errors and omissions are those of the author. Views expressed in this paper are those of the author and not necessarily those of the Africa Development Bank Group or its Board of Directors.

\section{Conflict of Interests}

The author declares that there is no conflict of interests regarding the publication of this paper.

\section{Acknowledgments}

This paper received comments from colleagues at the African Development Bank's Regional Resource Center in South Africa and participants at a workshop in Swaziland in 2013.

\section{Endnotes}

1. The 2002 SACU Agreement established a Common Revenue Pool consisting of all customs, excise, and additional duties collected in the common customs area. These resources are shared among the SACU member countries based on a formula:

$$
R_{i}=\frac{\left(M_{i}+P_{i} 1\right)}{\sum_{i=1}^{4}\left(M_{i}+P_{i}\right)} \times\left\{\left(C_{i}+E_{i}+S_{i}\right)\right\} \times 1.42,
$$

where $R_{i}=$ revenue of country $i$ (Botswana, Lesotho, Swaziland), $M_{i}=$ CIF imports of country $i, P_{i}=$ value of dutiable goods produced in country $i, C_{i}=$ sum of customs revenue in country $i, E_{i}=$ sum of excise revenue in country $i$, and $S_{i}=$ sum of sales tax revenue in country $i$ (Botswana, Lesotho, Swaziland). The full details of the CRP sharing formula are provided in Grynberg and Motswapong [21].

2. http://www.europarl.europa.eu/atyourservice/en/displayFtu.html?ftuId=FTU_4.2.1.html
3. R. Burgess, "The Southern African Development Community's Macroeconomic Convergence Program: Initial Performance," IMF, The African Department, SPN/ 09/14, June 15, 2009.

4. Weak governance or political instability could amplify fiscal instability and negatively impacts fiscal outcomes [22].

5. For an elaborate derivation of the fiscal sustainability indicators, refer to Blanchard [18] and Krejdl [9].

\section{References}

[1] J. Mongardini, D. Benicio, T. Fontaine, G. Pastor, and G. Verdier, "In the wake of the global economic crisis: adjusting to lower revenue of the Southern African customs union in Botswana, Lesotho, Namibia and Swaziland," IMF African Department Paper 11/1, International Monetary Fund, Washington, DC, USA, 2011.

[2] O. Basdevant, C. Baba, and B. Mircherva, "Macroeconomic vulnerabilities stemming from the global economic crisis: the case of Swaziland," IMF African Department Paper 11/7, IMF, Washington, DC, USA, 2011.

[3] O. Basdevant, D. Benicio, B. Mircherva, J. Mongardini, G. Verdier, and L.-F. Zanna, "The design of fiscal adjustment strategies in Botswana, Lesotho, Namibia and Swaziland," IMF Working Paper 11/266, International Monetary Fund, Washington, DC, USA, 2011.

[4] N. Chalk and R. Hemming, "Assessing fiscal sustainability in theory and practice," IMF Working Papers 00/81, International Monetary Fund, Washington, DC, USA, 2000.

[5] Central Bank of Swaziland, Quarterly Report, Central Bank of Swaziland, 2013.

[6] A. Fatás and I. Mihov, "The case for restricting fiscal policy discretion," The Quarterly Journal of Economics, vol. 118, no. 4, pp. 1419-1447, 2003.

[7] M. G. Arghyrou and K. B. Luintel, "Government solvency: revisiting some EMU countries," Journal of Macroeconomics, vol. 29, no. 2, pp. 387-410, 2007.

[8] N. Chalk and R. Hemming, "Assessing fiscal sustainability in theory and practice," IMF Working Paper 00/81, International Monetary Fund, Washington, DC, USA, 2006.

[9] A. Krejdl, "Fiscal sustainability-definition, indicators and assessment of Czech public finance sustainability," Working Paper Series 3/2006, Czech National Bank, Prague, Czech Republic, 2006.

[10] W. Fay and R. Porter, "Optimal budget deficits," Briefing Paper 28, Harvard Law School, Cambridge, Mass, USA, 2006.

[11] A. Carriero, C. A. Favero, and F. Giavazzi, "Fiscal sustainability: a new framework for tests and indicators," Mimeo, Università Bocconi, Milan, Italy, 2005.

[12] C. M. Reinhart and K. S. Rogoff, "This time is different: a panoramic view of eight centuries of financial crises," NBER Working Paper 13882, The National Bureau of Economic Research, 2008.

[13] S. V. Wijnbergen, "Fiscal deficits, exchange rate crises and inflation," The Review of Economic Studies, vol. 58, no. 1, pp. 8192, 1991.

[14] N. Budina and S. Wijnbergen, "Quantitative approaches to fiscal sustainability analysis: a new World Bank tool applied 
to Turkey," World Bank Policy Research Working Paper 4169, World Bank, Washington, DC, USA, 2007.

[15] B. Trehan and C. E. Walsh, "Common trends, the government's budget constraint, and revenue smoothing," Journal of Economic Dynamics and Control, vol. 12, no. 2-3, pp. 425-444, 1988.

[16] H. Bohn, "The behaviour of U.S. public debt and deficits," Quarterly Journal of Economics, vol. 113, pp. 949-963, 1998.

[17] O. Celasun, X. Debrun, and J. Ostry, "Primary surplus behaviour and risks to fiscal sustainability in emerging markets: a fan-chart approach," IMF Working Paper 0667, International Monetary Fund, Washington, DC, USA, 2005.

[18] O. J. Blanchard, "Suggestions for a new set of fiscal indicators," OECD Economics Department Working Paper 79, 1990.

[19] J. G. Mackinnon, "Numerical distribution functions for unit root and cointegration tests," Journal of Applied Econometrics, vol. 11, no. 6, pp. 601-618, 1996.

[20] International Organization of Supreme Audit Institutions, "The International Standards of Supreme Audit Institutions-Debt Indicators," 2010, http://www.intosai.org/.

[21] R. Grynberg and M. Motswapong, "SACU revenue sharing formula: towards a developmental agreement," Botswana Institute for Development Policy Analysis 32, Botswana Institute for Development Policy Analysis, 2012.

[22] R. Pasten and J. P. Cover, "The political economy of unsustainable fiscal deficits," Cuadernos de Economia, vol. 47, no. 136, pp. 169-189, 2010. 

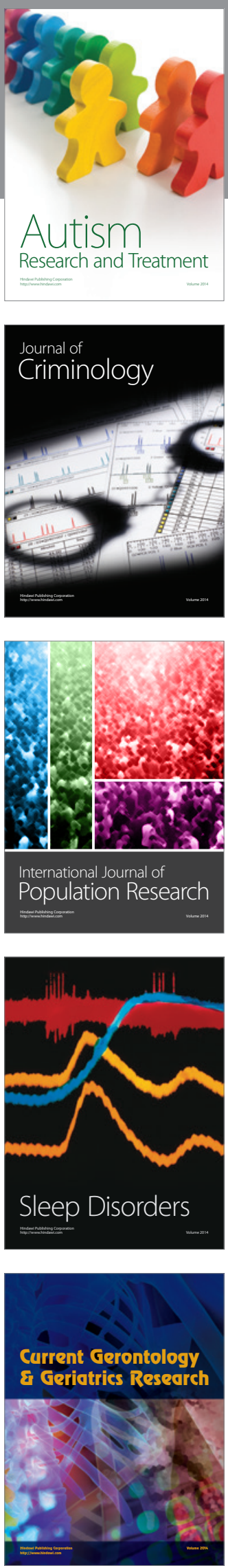
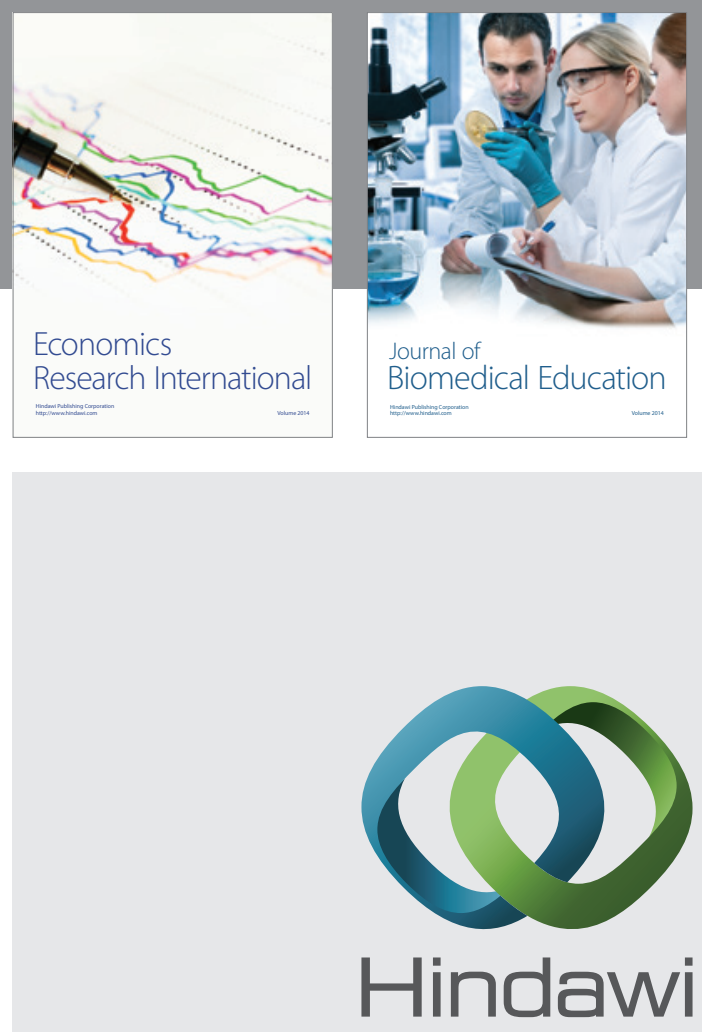

Submit your manuscripts at

http://www.hindawi.com
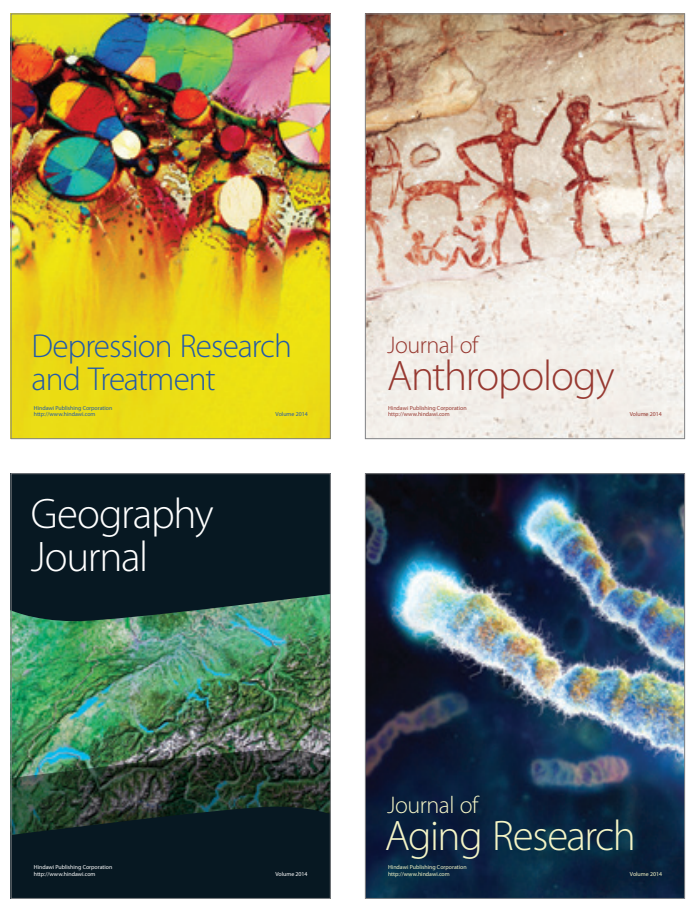
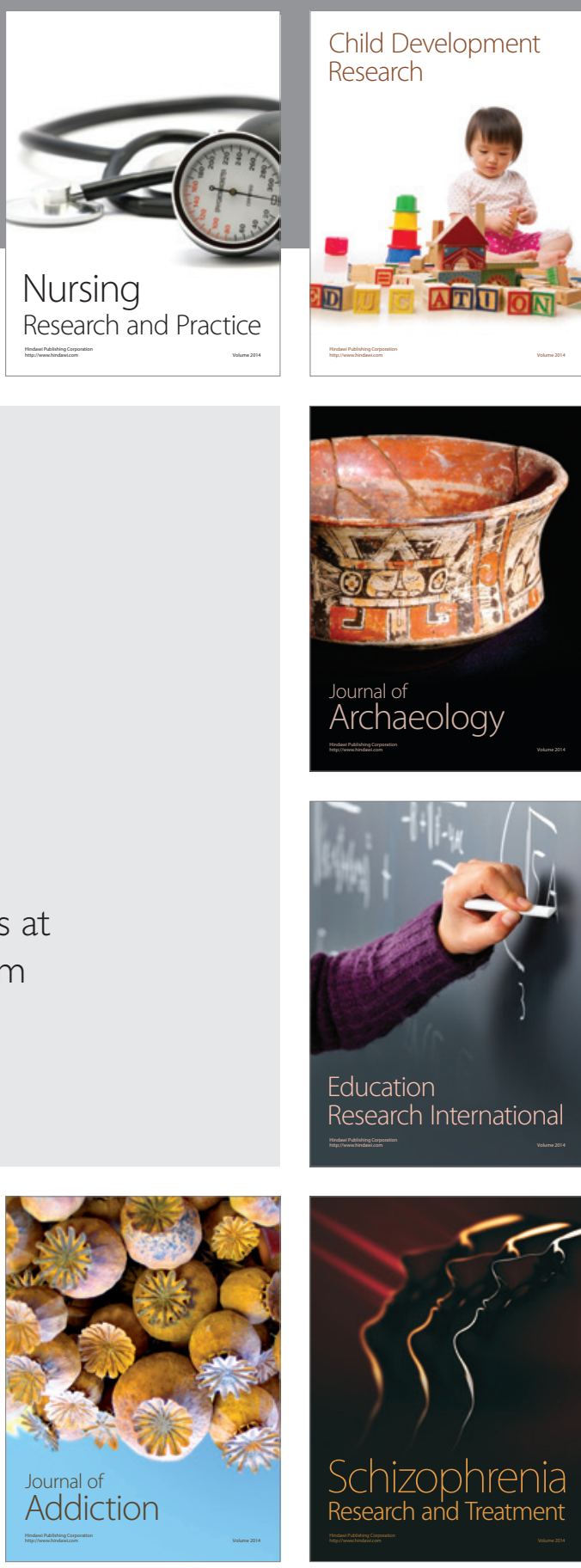

(D)
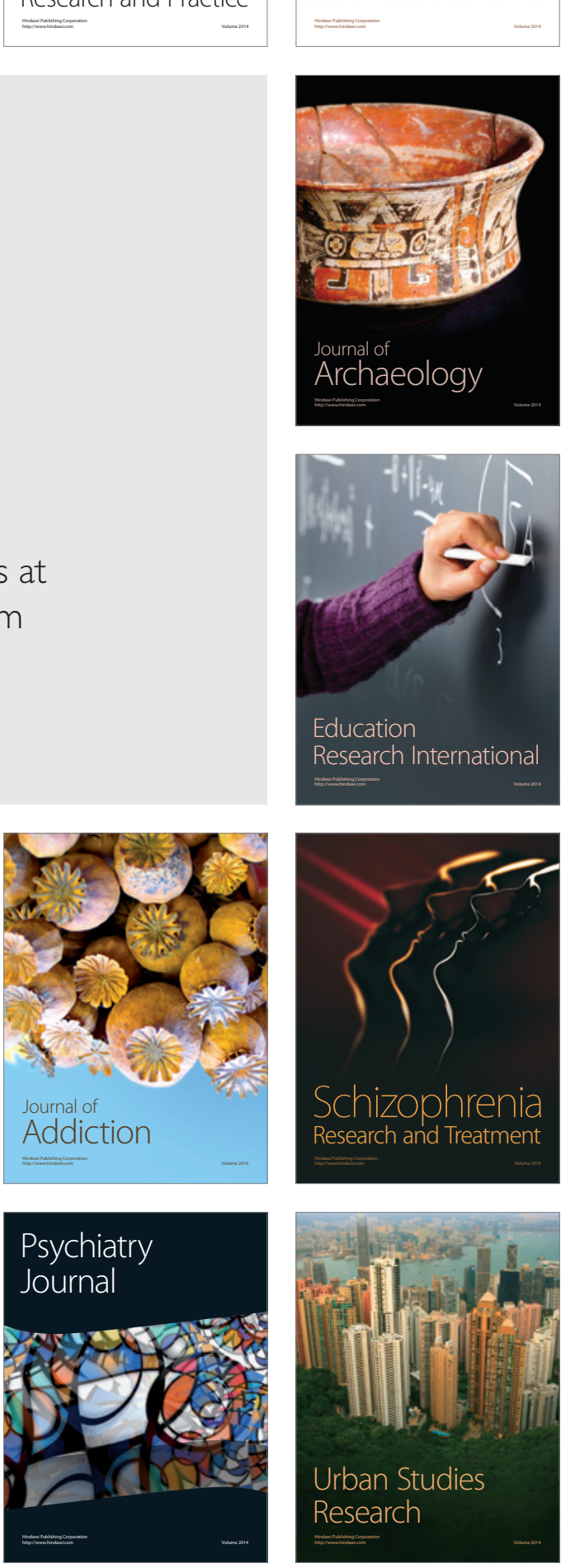